\title{
Variations in the surface velocity of an alpine cirque glacier
}

\author{
J. W. SANDERS, ${ }^{1}$ ๑ K. M. CUFFEY, ${ }^{1,2} \odot$ K. R. MACGREGOR, ${ }^{3}$ J. L. KAVANAUGH, ${ }^{4}$ \\ C. F. DOW ${ }^{5}$ \\ ${ }^{1}$ Department of Earth and Planetary Science, University of California Berkeley, Berkeley, CA 94720, USA \\ ${ }^{2}$ Department of Geography, University of California Berkeley, Berkeley, CA 94720, USA \\ ${ }^{3}$ Geology Department, Macalester College, St. Paul, MN 55105, USA \\ ${ }^{4}$ Department of Earth and Atmospheric Sciences, University of Alberta, Edmonton, AB T6G 2E3, Canada \\ ${ }^{5}$ Department of Geography and Environmental Management, University of Waterloo, Waterloo, ON, N2L 3G1, Canada \\ Correspondence: J.W. Sanders<johnnyw@uoregon.edu>
}

\begin{abstract}
Following pioneering work in Norway, cirque glaciers have widely been viewed as rigidly rotating bodies. This model is incorrect for basin-filling cirque glaciers, as we have demonstrated at West Washmawapta Glacier, a small glacier in the Canadian Rocky Mountains. Here we report observations at the same glacier that assess whether complex temporal variations of flow also occur. For parts of three summers, we measured daily displacements of the glacier surface. In one year, four short-duration speed-up events were recorded. Three of the events occurred during the intervals of warmest weather, when melt was most rapid; the fourth event occurred immediately following heavy rain. We interpret the speed-up events as manifestations of enhanced water inputs to the glacier bed and associated slip lubrication by increased water volumes and pressures. No further speed-ups occurred in the final month of the melt season, despite warm temperatures and several rainstorms; the dominant subglacial water system likely transformed from one of poorly connected cavities to one with an efficient channel network. The seasonal evolution of hydrology and flow resembles behaviors documented at other, larger temperate glaciers and indicates that analyses of cirque erosion cannot rely on simple assumptions about ice dynamics.
\end{abstract}

KEYWORDS: glacial geomorphology, ice velocity, mountain glaciers, subglacial processes

\section{INTRODUCTION}

'[Small glaciers] are the products of avalanches, the crushed ice being recompacted into a solid mass, which exhibits on a smaller scale most of the characteristics of the large glaciers.' - John Tyndall, The Glaciers of the Alps, 1896

Cirques are abundant and prominent features of glacially sculpted landscapes. Glaciers shape cirques both by directly eroding bedrock and by removing fragmentary products of weathering. Such action as geomorphological agents provides one motivation for studying glaciers occupying cirques. A second motivation is that cirque glaciers are often the last remnants of ice in warming landscapes, and their further evolution captivates interest.

The most widespread view of cirque glaciers, arising from work by Lewis in Norway during the 1950s (McCall, 1952; Lewis, 1960), characterizes their movement as nearly rigid rotation with rates of basal sliding far exceeding internal deformation. This end-member model is appealingly simple and has allowed scientists to essentially ignore ice dynamics in analyses of both cirque glaciers and cirque development and morphology (e.g. Weertman, 1971; Barr and Spagnolo, 2013; Mîndrescu and Evans, 2014). Although it may apply to some very thin and small ice bodies, this model is certainly wrong for glaciers of dimensions comparable to most cirques (Sanders and others, 2010). Dynamically, cirque glaciers in temperate environments are similar to larger temperate glaciers.

The dominance of the rigid-rotation model and the paucity of glaciological studies in cirques hinder the development of process-based understanding of cirque formation.
Although geomorphologists have studied cirques since the 19th century (e.g. Gastaldi, 1873), basic questions such as 'How rapidly did this cirque form?' or 'Why is one cirque overdeepened and another not?' are still unanswerable. Numerical models developed to probe such questions can provide valuable insights but remain poorly parameterized (MacGregor and others, 2009). Insufficient knowledge about cirque glaciers weakens arguments - such as the glacial buzzsaw theory - dependent on the morphology or geographic location of cirques (e.g. Porter, 1989; Mitchell and Montgomery, 2006; Anders and others, 2010).

We have previously reported results from our case study of a temperate cirque glacier in the Canadian Rockies, with a focus on the spatial pattern of flow and sliding (Sanders and others, 2010), subsurface hydrology (Kavanaugh and others, 2010; Dow and others, 2011, 2014), and processes of erosion and sediment transport (Sanders and others, 2013). The present manuscript aims to be a succinct report of observations of temporal variations in sliding motion of the glacier, and how such variations fit into the seasonal evolution of the subglacial hydrological system. We show that cirque glaciers can share the characteristic temporal behavior of larger temperate glaciers, on daily to seasonal timescales, including 'spring event' speed-ups. Apart from their inherent interest as manifestations of the coupled ice flow and hydrological system, temporal variations of slip rate hold interest for their possible connections to subglacial erosion. If erosion depends on slip rate in a non-linear manner, as appears likely (Hallet, 1979, 1996; Herman and others, 2015), the cumulative erosion of a glacier's bed depends not only on the net slip but also on how episodically 
or continuously the displacement occurs. Intervals of fast slip may also activate erosional processes associated with pulses of extreme pressure (Kavanaugh and others, 2010) and related phenomena.

In this paper, we first briefly summarize the typical behavior of temperate glaciers during the melt season, and then describe our field site and measurement strategies. We interpret our observations in the context of prior knowledge about coupling of basal slip and hydrology and their seasonal coevolution and briefly discuss some implications of our work with respect to the formation of cirques.

\subsection{Temporal evolution of a 'typical' temperate valley glacier}

Extensive study of the seasonal variation of temperate valley glacier behavior (including Meier, 1960; Paterson, 1965; Hodge, 1974; Iken, 1977; Hooke and others, 1983; Iken and others, 1983; Iken and Bindschadler, 1986; Naruse and others, 1992; Willis, 1995; Harper and others, 2002; Anderson and others, 2004; MacGregor and others, 2005) has led to the following phenomenological understanding. (In this section, citations direct the reader to a few specific examples and are not intended to be comprehensive.) Except under thin ice, the 'winter' configuration prevailing at melt season onset is characterized by small or absent subglacial cavities forming a weakly connected linked network on the bed (Willis, 1995; Nienow and others, 1998). Subglacial water pressure is typically high but the volume of water and its spatial extent are limited (Iken, 1981). Proglacial discharge varies diurnally only weakly (Nienow and others, 1998; Mair and others, 2002a; MacGregor and others, 2005), and the glacier slides slowly (Paterson, 1965).

As the melt season develops, meltwater and rain reach the bed and increase the volume of water in and under the ice, often also raising subglacial water pressures and lowering effective pressures (e.g. Iken and Bindschadler, 1986). Sustained low effective pressures and/or flooding of the bed lead to a period of enhanced basal slip lasting weeks to months (Paterson, 1965; Iken, 1977; Hooke and others, 1983; Gudmundsson and others, 2000; Harper and others, 2002; Sugiyama and Gudmundsson, 2004). Slip rates increase transiently because high water pressures push on downglacier-dipping ice faces, and increased water volume separates the glacier sole from drag-producing roughness (Iken, 1981; Humphrey, 1987; Harper and others, 2002; Cuffey and Paterson, 2010). Weakening of subglacial till can also play a role (Willis, 1995).

Short-term, very rapid basal slip triggered by pulses of meltwater input sometimes occur. During these 'motion events', the glacier exhibits several phenomena. Surface speed can be several times above the background level (Gudmundsson and others, 2000; Anderson and others, 2004). In some cases, these occur in isolated locations; in others they progress up- or down-glacier at several hundred meters per day (Hodge, 1974; Gudmundsson and others, 2000; Anderson and others, 2004; MacGregor and others, 2005). Transient, rapid slip can also cause vertical motion and changes of the glacier surface elevation relative to prevailing trends (Iken and others, 1983; Hooke and others, 1989; Mair and others, 2002b; Anderson and others, 2004; MacGregor and others, 2005). Such 'uplift' events result, specifically, from cavity growth, longitudinal strain and shearinduced dilation of subglacial till (Iken and others, 1983;
Hooke and others, 1989; Sugiyama and Gudmundsson, 2004). Lastly, rapid slip can also result in redistribution of resistive stresses (Kavanaugh and Clarke, 2001).

Later in the melt season, water flowing at the bed allows the subglacial drainage network to evolve into a highefficiency channel network (Nienow and others, 1998; Fountain and Walder, 1998). Effective drainage of water reduces basal water pressures and volumes. Consequently, the glacier slows and subglacial cavities begin to close. Pulses of water delivered to the bed tend to pass quickly through the glacier with only weak effects on the ice flow.

\section{SITE DESCRIPTION AND FIELD MEASUREMENTS}

\subsection{West Washmawapta Glacier}

We instrumented West Washmawapta Glacier, a small $\left(1 \mathrm{~km}^{2}\right)$, temperate glacier occupying an east-facing cirque carved in Helmet Mountain (elevation: $3124 \mathrm{~m}$ ) of the Vermilion Range of British Columbia, Canada (Fig. 1). The glacier has been retreating since at least 1949. The glacier surface is steep below the headwall $\left(20-40^{\circ}\right)$ and above the lee side of the riegel, but relatively flat $\left(4-8^{\circ}\right)$ across a central overdeepened bowl (Figs 1, 2). In 2006, the average ice thickness was $70 \mathrm{~m}$ and the maximum ice thickness was $\sim 185 \mathrm{~m}$. The glacier generally flows northeastward with average surface speeds of $3-10 \mathrm{~m} \mathrm{a}^{-1}$. Basal slip is negligible in the central bowl but increases toward the northern margin and the riegel, where slip accounts for $\sim 70 \%$ of total motion in both regions (Sanders and others, 2010). Basal water pressure was measured in boreholes for almost a full year between 18 August 2007 and 8 August 2008. In late summer, water pressure varied diurnally, but overwinter, it remained consistently high ( $>90 \%$ of overburden) with occasional spikes and dips (Dow and others, 2014). Coarsely crystalline and sediment-rich ice sits directly on bedrock in marginal regions accessed by tunnels (Sanders and others, 2013), but a basal till layer may be present elsewhere. Using a camera lowered into boreholes, we identified clasts and clumps of sediment dispersed throughout the ice column; in some holes we encountered turbid water near the bed.

Extensive information about the site and our scientific methods were reported in Kavanaugh and others (2010), Sanders and others (2010), Dow and others (2011, 2014) and Sanders and others (2013). The measurements described below were collected between 28 June-18 August 2006, 12 May-28 August 2007 and 30 June-23 August 2018. The GPS devices and stream gauges ran automatically in our absence and, occasionally, experienced battery or mechanical failures that caused gaps of up to 2 weeks in our measurements.

\subsection{Hydrology, water balance and weather}

Downstream of West Washmawapta Glacier, all of the runoff coalesces into a single-thread bedrock channel. Discharge in this channel also includes runoff from a nearby, separate glacier, and we therefore installed two stream gauges to isolate the contributions (Fig. 2, labeled stream gauge 1 and stream gauge 2). The gauges operated in 2006 and 2007; no discharge measurements were obtained in 2008. We performed salt-discharge measurements at both sites simultaneously over the course of several days (Kite, 1994; Sanders and others, 2013) in order to develop rating curves 


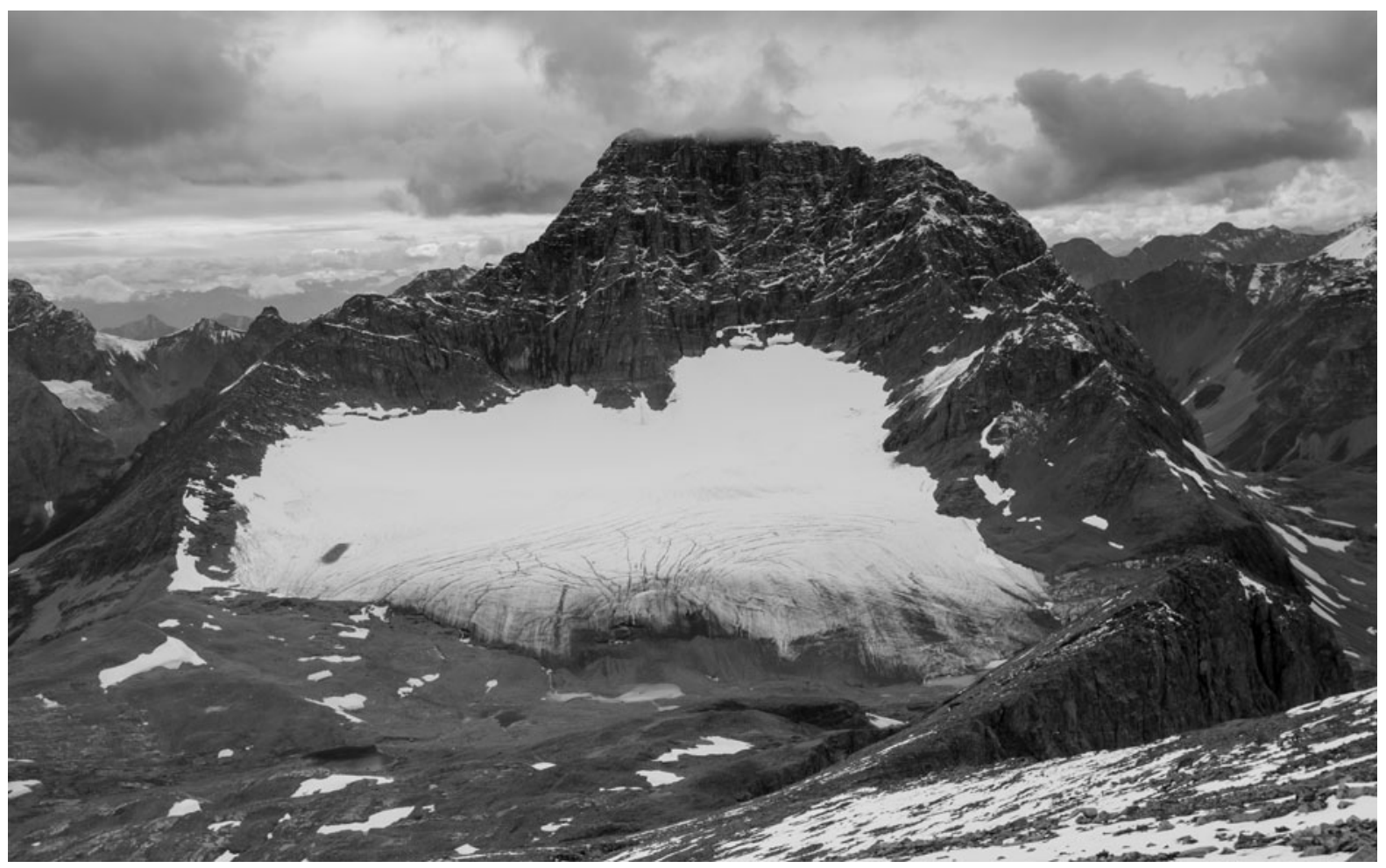

Fig. 1. Head-on view of West Washmawapta Glacier taken from the east in August 2008. Here a recent snowstorm hides the fact that the snowline has retreated well within the cirque. Outlet streams emerge from the toe in numerous locations. The glacier is $\sim 1 \mathrm{~km}$ across and $1 \mathrm{~km}$ long.

between stage and discharge for both gauges. Stage was measured with a Druck PDCR 1230 pressure transducer at stream gauge 1, and with a Campbell Scientific SR50 Sonic Ranging Sensor at stream gauge 2. A malfunction at gauge 2 erased data collected before 12 July 2007. To extend the record back in time, we extrapolated using the late-summer relationship between stream gauge 1 and $2\left(r^{2}=0.94\right)$; during this period, the errors are therefore larger. For this reason, and because our glacier velocity data are daily averages (see below), we report proglacial discharge as daily totals. In mid and late summer, water discharge in the proglacial streams varies with a strong diurnal cycle. In winter, however, the streams and proglacial lakes are dry. See Sanders and others (2013) for more information about the stream monitoring. No attempt was made to correct for changes in stored water volume within the proglacial lakes, because during the period of analysis (mid and late summer), the lakes remain filled and such changes are small; the entire volume of the lakes is equivalent to $\sim 1 \mathrm{~d}$ of discharge from the basin.

Air temperature was recorded hourly at weather stations installed both on and off the glacier (Fig. 2). A tippingbucket rain gauge, situated at stream gauge 1, measured rainfall. In summer, storms were typically of high intensity and short duration, rarely lasting more than $2 \mathrm{~d}$. Afternoon thunderstorms were common. Occasionally, storms blanketed the cirque with snow and reduced proglacial discharge significantly for a day or two. At the on-glacier weather station, we measured the change in snow surface elevation with a downward-looking sonic sensor similar to that found at stream gauge 2 .

We used the observed daily discharge, precipitation and snow surface lowering records to estimate a cirque-wide relative water balance between 3 July 2007 and 27 August
2007 (as the onset of melt preceded installation of our stream gauges, the absolute balance is not known). The water balance is defined so that positive values indicate storage of water within and beneath the glacier, while negative values indicate loss. For this rough calculation, we assumed rainfall and melt were uniform over the glacier and that the snow and ice density were everywhere 500 and $910 \mathrm{~kg} \mathrm{~m}^{-3}$, respectively. We ignored rainfall on the headwall and foreland because (1) their combined contributions to the balance are at least a factor of 10 smaller than melt and rain on the glacier and (2) karst features in the cirque bedrock make estimating infiltration loss challenging. Lastly, uncertainties in water inputs and exfiltration are large, so we adjusted the net balance rate by a constant offset selected to assure that late-season water storage is negligible. This assumption is plausible given that late in the summer, stream discharge was strongly diurnal and no speed-ups occurred (see below). In any case, this adjustment has little impact on the shorter term variations of balance that are of primary interest here.

\subsection{Ice surface velocity}

We installed continuously running Trimble 5700 GPS receivers on the glacier surface to measure displacement. Herein, we identify receivers by the year of installation followed by a letter; for example, GPS receiver A in year 2006 is called 6A. The antennas were attached to a triangular piece of plastic mounted on three $3 \mathrm{~m}$ long steel poles set into the ice or snow surface (as in Fig. 2 of Anderson and others, 2004). Two reference stations were installed on bedrock within 1 $\mathrm{km}$ of the on-glacier receivers (Fig. 2). The number of GPS receivers and duration of measurements varied from year to year. No receivers operated over the winter. In 2006, we 


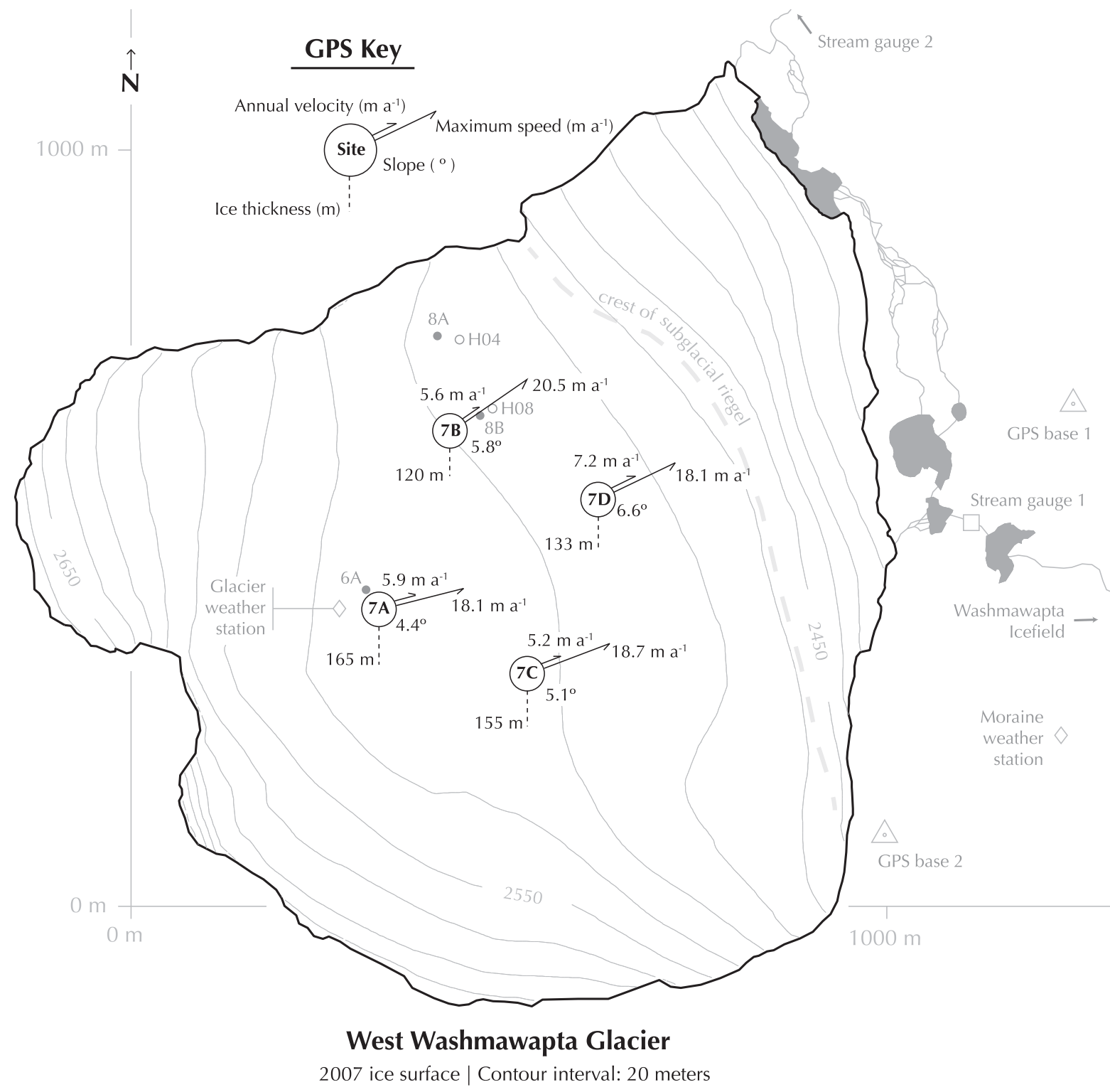

Fig. 2. Map of West Washmawapta Glacier showing locations of continuous GPS stations, GPS base stations, stream gauges, the boreholes and weather stations. For the 2007 GPS sites only, the annual ('winter') surface velocity, peak surface velocity, surface slope and ice thickness are shown. Stream gauge 2 is located just north of the map boundary. The glacier center is located at $51.1773^{\circ} \mathrm{N}, 116.3296^{\circ} \mathrm{W}$.

installed two receivers on 25 June, one of which (6A) functioned and collected data until 18 August. The other's antenna support failed. The following year, in order to span the entire melt-season, we arrived on site in mid-May and installed four stations (Fig 2, stations 7a-d). The glacier was completely snow-covered at this time. In June, when we returned for maintenance, all but a small area near the margin remained snow-covered. The GPS stations operated until 26/27 August. Temporary battery failure following burial of the solar panels by snow led to three gaps in the 2007 displacement records. In 2008, our arrival was delayed until late June. We installed two receivers ( $8 \mathrm{~A}$ and 8B) along the northern margin near two boreholes used for subglacial measurements (Fig. 2). These receivers operated from 29 June until 23/24 August.

In all seasons, the GPS receivers recorded data every $15 \mathrm{~s}$ for $24 \mathrm{~h}$ at a time. These data were subsequently converted to Rinex format, divided into $1 \mathrm{~h}$ intervals using TEQC, and post-processed in Trimble Geomatics Office ${ }^{\mathrm{TM}}$. We quantified horizontal and vertical error magnitude by assuming that random lateral and vertical shifts in position to either side of the prevailing velocity vector were error-induced. Horizontal and vertical position errors were both $\sim 5 \mathrm{~mm}$, which is equivalent to a velocity error of $\pm 2 \mathrm{~m} \mathrm{a}^{-1}$. At West Washmawapta Glacier, where the ice moves slowly, the trade-off between temporal resolution and error magnitude did not allow us to resolve velocity variations lasting $<1 \mathrm{~d}$. We used stable periods of motion to remove background trends in the vertical motion arising from snow-settling, bed-parallel flow and time-invariant longitudinal strain.

\section{RESULTS AND DISCUSSION}

\subsection{Temporal variations in surface velocity at the study site}

Figure 3 illustrates the surface horizontal speed anomalies for all 3 years. Excepting the first few days of measurement, when uncertainties were larger and support poles may have been settling, in 2006 and 2008, the glacier moved 

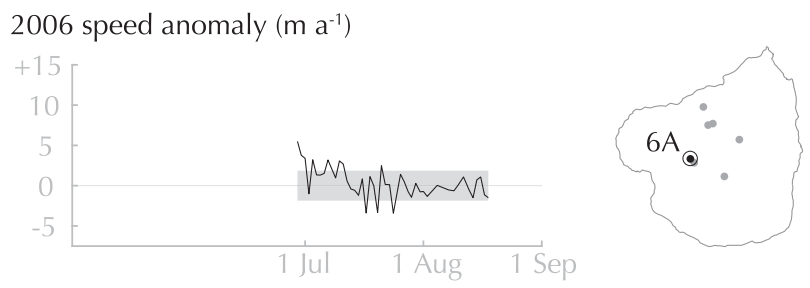

2007 speed anomaly $\left(\mathrm{m} \mathrm{a}^{-1}\right)$
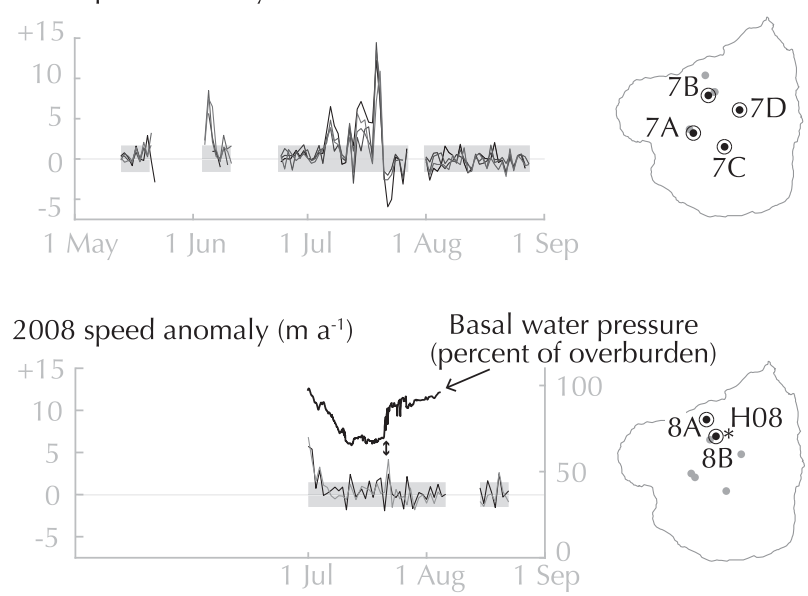

Fig. 3. Surface speed anomalies, defined as instantaneous speed minus the annual average, are shown for melt seasons 2006-08 (left axes); the locations of each GPS are shown on the map to the right. Speed error magnitude is shown by the gray translucent box behind the velocity records; speed fluctuations outside these boxes are considered 'real' rather than noise. In 2008, the only summer with basal water pressure measurements, a double-ended arrow marks a probable motion event and the concomitant spike in pressure. Borehole $\mathrm{HO} 8$ is shown with an asterisk.

steadily and horizontal speeds remained near the annual averages. In 2008, GPS 8A and 8B recorded a low-magnitude velocity spike, marked with an arrow on the figure, coincident with rising water pressure at the nearest borehole (Fig. 3, bottom panel). A brief speed-up during rising pressure plausibly reflects hydraulic jacking and cavity growth. The similarity of speeds before and after the event, at times of different basal water pressures, conforms with theoretical expectations that basal water pressure does not necessarily influence sliding rate; for certain bed configurations, the water volume can increase or decrease, affecting sliding rate by drowning rough areas, without a coincident change of water pressure (Humphrey, 1987; Harper and others, 2002; Cuffey and Paterson, 2010). Alternatively, the measured water pressure may not be indicative of conditions in a large enough region of the bed to influence flow.

The remainder of this discussion focuses on the 2007 data, our longest record (Fig. 3, middle panel). Figure 4 illustrates several aspects of the spring/summer melt season in detail. Four motion events - short-term, rapid increases in speed are evident in the velocity record (Fig. 4, labels 1-4). All four events coincided with upward surface motion relative to the prevailing vertical trajectory. It appears that all four events occurred during periods of increasing water input to the bed; three corresponded to the warmest weather intervals when melt rate was largest, and one coincided with intense rain. We interpret the strong response of slip rate to influxes of water as a manifestation of increased basal water volume and pressure caused by inadequate drainage along the bed, as expected during the transition from an inefficient drainage system to an efficient one. Enhanced water inflows encounter a basal hydrological system of linked cavities and sediment porosity not well-integrated with channels (Mair and others, 2002a) or small conduits adjusted to much lower discharges. The following observations underlie our interpretations.

\subsubsection{Motion event 1}

In May, when measurements began, the glacier was moving at the 'winter velocity', a combination of internal deformation and basal slip that varied from site to site (Sanders and others, 2010). On 4 June, after several days of warm weather, GPS receivers $7 \mathrm{~B}-\mathrm{D}$ recorded rapid acceleration (7A was inoperative), reaching peak single-day velocities 2-2.5 times the annual average. A small but spatially consistent surface uplift also occurred. The steep decline in the snow surface elevation (which re-exposed the solar panels) prior to the event indicates significant melt occurred. Soon thereafter, however, a storm deposited new snow, melt ceased, and velocities returned to their background values. The GPS receivers shut-off again, causing the second data gap.

\subsubsection{Motion event 2}

A warming trend between 1 July and 5 July, attended by increasing proglacial discharge and a positive water balance, led to motion event 2. Although the peak velocities during this event were slightly lower than event 1 (1.5-2.1 times the average), surface uplift was larger. As before, a sharp drop in air temperature caused the event to end. Proglacial discharge declined and the water storage fell at the same time. Motion event 2 lasted $4 \mathrm{~d}$.

\subsubsection{Motion event 3}

This event occurred during the hottest period of the summer (12-16 July). The event was distinct in a few ways. First, it was observed only at the two stations situated on a common flowline, 7A and 7D, and not at the stations located just a few hundred meters transversely on either side. Although 7C did not accelerate horizontally, it did appear to uplift. Second, the acceleration was interrupted by a pronounced $1 \mathrm{~d}$ drop in velocity. Third, as in event 2 , the water balance began to decline as soon as the high slip rate was attained. At the end of the event, velocity at the downstream site, 7D, returned to the background value, whereas at the upstream site, 7A, it remained partially elevated. We surmise the ice at $7 \mathrm{~B}$ and $7 \mathrm{C}$ was frictionally locked to the bed and did not experience a sufficient lateral push to initiate slip.

\subsubsection{Motion event 4}

The fourth and final motion event of the season (Fig. 4) was the largest, with peak velocities of 2.5-3.6 times the annual average. Unlike the first three events, which followed periods of rapid melt, motion event 4 coincided with heavy rain. Direct rainfall and rainfall-induced melt drove the water balance to the season's maximum. Proglacial discharge also reached its maximum soon thereafter. Surface uplift occurred with similar magnitudes at all four stations. The glacier exhibited plug-like horizontal motion (maximum velocities at sites $7 \mathrm{~A}-7 \mathrm{C}$ were essentially identical) within our region of observation.

The effects of event 4 on subglacial hydrology and ice velocity persisted through the remainder of the summer season. In the immediate aftermath, surface velocities dropped below 


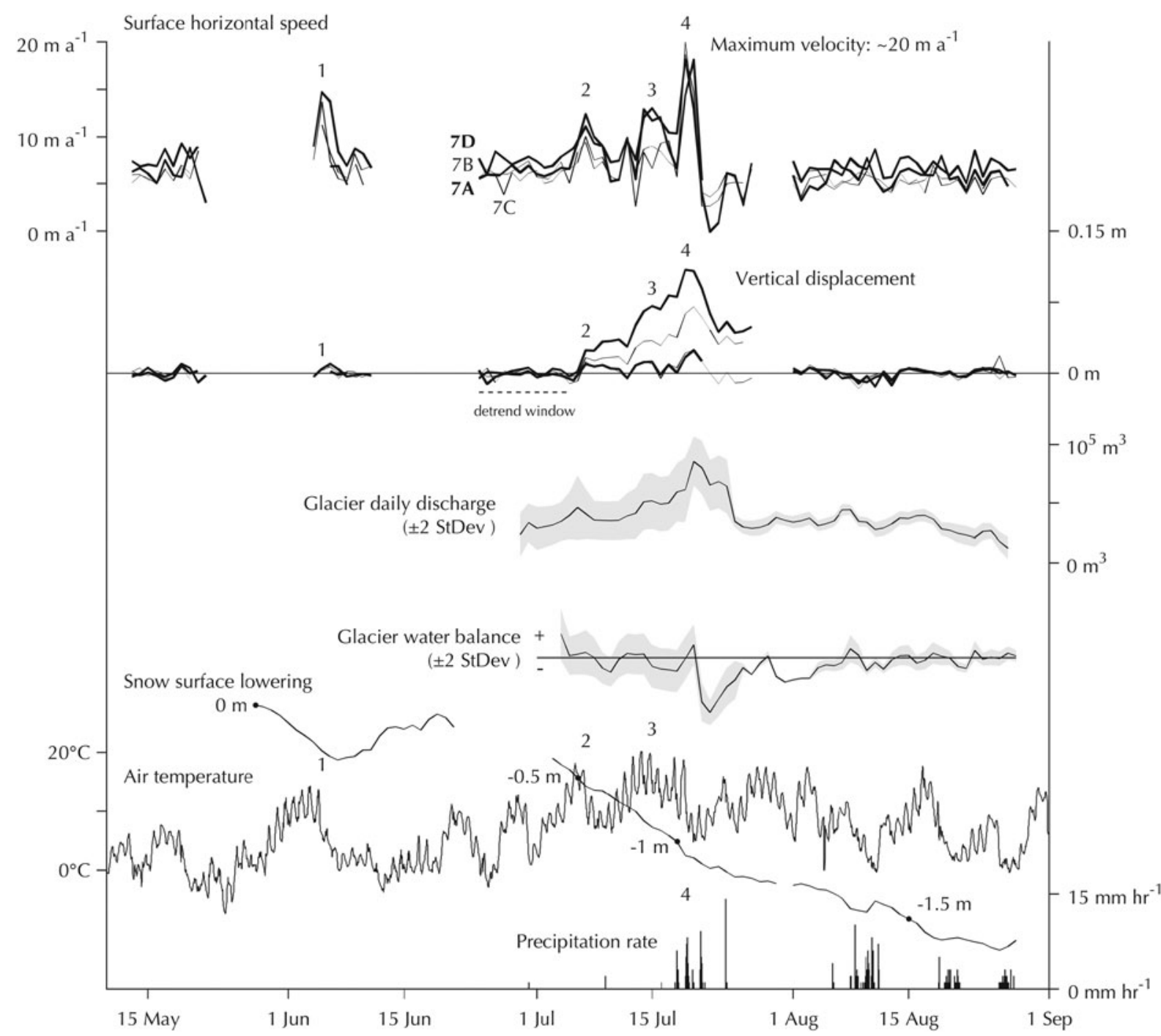

Fig. 4. Summary of data collected during the 2007 melt season. The four motion events are marked by the numbers 1-4. Gaps in the horizontal speed and vertical motion records were caused by insufficient battery capacity or collapse of the GPS antennas. Units are displayed along the $y$-axis.

background speed and the surface subsided (nearly $7 \mathrm{~cm}$ at 7A), plausibly an indication of cavity collapse (Iken, 1981). The pronounced reduction in water storage lends support to this interpretation. Furthermore, event 4 apparently caused an increase in the efficiency of the subglacial drainage network, as indicated by: (1) the rapid decline of water storage indicating rapid subglacial water flow, and (2) neither subsequent storms (e.g. on 23 July and 8-10 August) nor warm temperatures (16 August) caused additional motion events. On the contrary, surface speeds remained below the annual average for two weeks; only once water storage stopped declining did speed return to the winter value.

\section{DISCUSSION}

The evolution of West Washmawapta Glacier in summer 2007 was essentially the same as that previously reported for other, larger temperate glaciers. Before the onset of melt, glacier motion was slow and nearly steady. The spring/summer transition included multiple short-lived motion events triggered by melt or rainfall. During the motion events, speed increased and the surface uplifted, both manifestations of faster basal slip. After the final motion event, surface speeds returned to and maintained their 'winter' values despite episodes of enhanced water inputs to the bed. This sequence is consistent with a hydrological transition from an inefficient, linked-cavity or restricted conduit network along the glacier bed to an efficient, channelized system.

The surface uplift that occurred during motion events warrants further discussion. Uplift during motion events could result from either cavity growth or vertical strain in the glacier or both (Hooke and others, 1989), or dilation of basal sediments. Because cavity growth is important for glacial erosion (Iverson, 1991; Hallet, 1996), but vertical strain is not, we would like to deduce the cause of the uplift. The evidence indicates that cavity growth is the more likely cause. First, measured velocities at stations 7A and 7D, which are situated nearly along a common flowline, do not reveal sufficient compressive longitudinal strain during the events (e.g. during event 2, the longitudinal strain rate is a factor of $\sim 5$ too small to explain the measured vertical displacement). The annual-averaged flow is faster down-glacier than up-glacier, yet the increases in speed were of the same magnitude in events 3 and 4, and nearly so in event 2 . Second, the prevailing longitudinal strain 
rates at each GPS station are small and extensional (Sanders and others, 2010), so that any multiplicative enhancement of the background speed would increase longitudinal extension and drive subsidence of the surface instead of the measured uplift. We also note that the amount of uplift during each motion event, given the cumulative horizontal displacement that occurred, is commensurate with realistic subglacial bedrock topography. Basal slip up stoss faces with angles of $8-20^{\circ}$, which exist throughout the proglacial zone, can entirely explain the observed uplift magnitude.

Our observations at West Washmawapta Glacier raise many unanswered questions highlighting the potentially complex interactions occurring in cirques and the numerous opportunities for further inquiry. For example, are motion events typical of most cirque glaciers? Are they favored by overdeepenings? West Washmawapta Glacier, due to its $>60 \mathrm{~m}$ overdeepening, is thicker than many glaciers of similar spatial extent; cavities should therefore collapse more rapidly than can be expected under thin glaciers. The glacier surface above the overdeepening is comparatively flat, reducing potential gradients along the bed beneath. Both factors perhaps increase the likelihood of motion events. Is there a limiting cirque glacier size beneath which a seasonal evolution of the subglacial hydrologic network does not occur? Smaller volumes of melt and rainfall will reach the beds of smaller cirque glaciers. Subglacial water pressure and volume thus may never reach levels necessary to trigger a motion event.

From the geomorphological perspective, the role of motion events in cirque formation also remains unknown. At our study site, the percentage of cumulative annual basal slip varied from place to place: slip during motion events accounted for $5 \%$ of the annual total at GPS 7B, $20-50 \%$ at $7 \mathrm{D}$ and $70-100 \%$ at $7 \mathrm{~A}$. How relevant these numbers are to cirque erosion depends on the non-linearity of the relationship between erosion rate and basal slip rate, and under which glacial conditions they apply. Might motion events in cirques be restricted to interglacial periods when the glacier is small, melt is rapid, and rainstorms more intense?

\section{CONCLUSIONS}

We measured the surface velocity of a small alpine cirque glacier during parts of three melt seasons. Little temporal variability was observed during the first and third years. During the second year - the only year we began measurement before the onset of melt - four 'motion events' occurred. During each motion event, horizontal speed increased significantly (a factor of $\sim 2-3$ times normal) and the surface uplifted, the latter probably reflecting cavity formation rather than vertical strain. The first three motion events were triggered by melt of ice and snow, while the final and largest event was caused by a rainstorm. The volume of water flowing beneath the glacier during the final event was sufficient to transform the dominant subglacial hydrological system from an inefficient, linked-cavity system to an efficient, channelized network. Subsequent rainstorms and warm weather failed to produce additional motion events. The spring/summer transition was therefore essentially identical to that described at other, larger glaciers.

Our results offer further inducement (cf. Sanders and others, 2010) for abandoning the common view of cirque glaciers as simple, rigidly rotating ice bodies. In particular, existing theories of cirque formation should be viewed with skepticism, given how little is actually known about glaciers in cirques.

\section{ACKNOWLEDGEMENTS}

The authors wish to thank J. Moore, J. Cooper, M. Dain, L. Webb, L. Johnson, C. Miller, V. Legakis, T. Tobin, S. Belknap, E. Evans, I. Nicholson, A. Bliss, Y. Adachi, D. Galic and J. Beckers for outstanding assistance in the field. D. McTighe, C. Ward, P. Quanstrom and R. Harris of Alpine Helicopters were critical to making our project a success. We also thank R. Leb. Hooke and an anonymous reviewer for comments that helped us clarify our thoughts and improve this manuscript. This report is based on work funded by NSF grant EAR-0518608 to KMC, grant EAR0517967 to KRM, a NSERC Discovery grant to JLK and an Alberta Ingenuity Graduate Scholarship to CFD. KMC thanks The Martin Family Foundation for additional support.

\section{REFERENCES}

Anders AM, Mitchell SG and Tomkin JH (2010) Cirques, peaks, and precipitation patterns in the Swiss Alps: connections among climate, glacial erosion, and topography. Geology, 38, 239-242

Anderson RS and 6 others (2004) Strong feedbacks between hydrology and sliding of a small alpine glacier. J. Geophys. Res., 109, F03005 (doi: 10.1029/2004JF000120)

Barr ID and Spagnolo M (2013) Paleoglacial and paleoclimatic conditions in the NW Pacific, as revealed by a morphometric analysis of cirques upon the Kamchatka Peninsula. Geomorphology, 192, 15-29

Cuffey KM and Paterson WSB (2010) The physics of glaciers, 4th edn. Butterworth-Heinemann, Oxford

Dow CF, Kavanaugh JL, Sanders JW, Cuffey KM and MacGregor KR (2011) Subsurface hydrology of an overdeepened cirque glacier. J. Glaciol., 57(206), 1067-1078

Dow CF, Kavanaugh JL, Sanders JW and Cuffey KM (2014) A test of common assumptions used to infer subglacial water flow through overdeepenings. J. Glaciol., 60(222), 725-734

Fountain AG and Walder JS (1998) Water flow through temperate glaciers. Rev. Geophys., 36(3), 299-328

Gastaldi SB (1873) On the effects of glacier-erosion in Alpine valleys. Q. J. Geol. Soc., 29(1-2), 396-401 (doi: 10.1144/GSL. JGS.1873.029.01-02.30)

Gudmundsson GH and 5 others (2000) High-resolution measurements of spatial and temporal variations in surface velocities of Unteraargletscher, Bernese Alps, Switzerland. Ann. Glaciol., 31, 63-68

Hallet B (1979) A theoretical model of glacial abrasion. J. Glaciol., 23(89), 39-50

Hallet B (1996) Glacial quarrying: a simple theoretical model. $A$. Glaciol., 22, 1-8

Harper JT, Humphrey NF and Greenwood MC (2002) Basal conditions and glacier motion during the winter/spring transition, Worthington Glacier, Alaska, USA. J. Glaciol., 48(160), 42-50

Herman F and 8 others (2015) Erosion by an Alpine glacier. Science, 350(6257), 193-195

Hodge SM (1974) Variations in the sliding of a temperate glacier. J. Glaciol., 13(69), 349-369

Hooke R Leb, Brzozowski J and Bronge C (1983) Seasonal variations in surface velocity, Storglaciären, Sweden. Geogr. Ann. A, 65(3-4), 263-277

Hooke R Leb, Calla P, Holmlund P, Nilsson $M$ and Stroeven A (1989) A 3 year record of seasonal variations in surface velocity, Storglaciären, Sweden. J. Glaciol., 35(120), 235-247

Humphrey NF (1987) Coupling between water pressure and basal sliding in a linked-cavity hydraulic system. IAHS Publ. 170 (Symposium at Vancouver 1987 - The Physical Basis of Ice Sheet Modelling), 105-119

Iken A (1977) Variations of surface velocities of some Alpine glaciers measured at intervals of a few hours. Comparison with Arctic glaciers. Z. Gletscherkd. Glazialgeol., 13(1/2), 23-35 
Iken A (1981) The effect of the subglacial water pressure on the sliding velocity of a glacier in an idealized numerical model. J. Glaciol., 27(97), 407-421

Iken A and Bindschadler RA (1986) Combined measurements of subglacial water pressure and surface velocity of Findelengletscher, Switzerland: conclusions about drainage system and sliding mechanism. J. Glaciol., 32(110), 101-119

Iken A, Röthlisberger H, Flotron A and Haeberli W (1983) The uplift of Unteraargletscher at the beginning of the melt season - a consequence of water storage at the bed? J. Glaciol., 29(101), 28-47

Iverson NR (1991) Potential effects of subglacial water-pressure fluctuations on quarrying. J. Glaciol., 37(125), 27-36

Kavanaugh JL and Clarke GKC (2001) Abrupt glacier motion and reorganization of basal shear stress following the establishment of a connected drainage system. J. Glaciol., 47(158), 472-480

Kavanaugh JL, Moore PL, Dow CF and Sanders JW (2010) Using pressure pulse seismology to examine basal criticality and the influence of sticky spots on glacial flow. J. Geophys. Res., 115, F04025 (doi: 10.1029/2010JF001666)

Kite G (1994) Measuring glacier outflows using a computerized conductivity system. J. Glaciol., 40(134), 93-96

Lewis WV (1960) The problem of cirque erosion. In Lewis WV ed. Norwegian cirque glaciers. Royal Geographical Society, London (Research Series 4), 97-100

MacGregor KR, Riihimaki CA and Anderson RS (2005) Spatial and temporal evolution of rapid basal sliding on Bench Glacier, Alaska, USA. J. Glaciol., 51(152), 49-63

MacGregor KR, Anderson RS and Waddington ED (2009) Numerical modeling of glacial erosion and headwall processes in alpine valleys. Geomorphology, 103, 189-204

Mair D, Nienow P, Sharp MJ, Wohlleben T and Willis I (2002a) Influence of subglacial drainage system evolution on glacier surface motion: Haut Glacier d'Arolla, Switzerland. J. Geophys. Res., 107(B8), 2175 (doi: 10.1029/2001JB000514)

Mair D, Sharp MJ and Willis IC (2002b) Evidence for basal cavity opening from analysis of surface uplift during a high-velocity event: Haut Glacier d'Arolla, Switzerland. J. Glaciol., 48(161), 208-216
McCall JG (1952) The internal structure of a cirque glacier. Report on studies of the englacial movements and temperatures. J. Glaciol., 2(12), 122-131

Meier MF (1960) Mode of flow of Saskatchewan Glacier, Alberta, Canada. USGS Prof. Pap., 424B, B14-B16

Mîndrescu M and Evans IS (2014) Cirque form and development in Romania: allometry and the buzzsaw hypothesis. Geomorphology, 208, 117-136

Mitchell SG and Montgomery DR (2006) Influence of a glacial buzzsaw on the height and morphology of the Cascade Range in central Washington State, USA. Quat. Res., 65, 96-107

Naruse R, Fukami H and Aniya M (1992) Short-term variations in flow velocity of Glacier Soler, Patagonia, Chile. J. Glaciol., 38 (128), 152-156

Nienow P, Sharp M and Willis I (1998) Seasonal changes in the morphology of the subglacial drainage system, Haut Glacier d'Arolla, Switzerland. Earth Surf. Process. Landf., 23, 825-843

Paterson WSB (1965) Variations in velocity of Athabasca Glacier with time. J. Glaciol., 5, 277-285

Porter SC (1989) Some geological implications of average Quaternary glacial conditions. Quat. Res., 32, 245-261 (doi: 10.1016 /0033-5894(89)90092-6)

Sanders JW, Cuffey KM, MacGregor KR, Kavanaugh JL and Dow CF (2010) Dynamics of an alpine cirque glacier. Am. J. Sci., 310, 753-773 (doi: 10.2475 /08.2010.03)

Sanders JW, Cuffey KM, MacGregor KR and Collins BD (2013) The sediment budget of an alpine cirque. Geol. Soc. Am. Bull., 125(1/ 2), 229-248

Sugiyama S and Gudmundsson GH (2004) Short-term variations in glacier flow controlled by subglacial water pressure at Lauteraargletscher, Bernese Alps, Switzerland. J. Glaciol., 50 (170), 353-362

Tyndall J (1896) The Glaciers of the Alps, new edition. Longsman Green, and Company, London

Weertman J (1971) Shear stress at the base of a rigidly rotating cirque glacier. J. Glaciol., 10(58), 31-37

Willis IC (1995) Intra-annual variations in glacier motion: a review. Prog. Phys. Geogr., 19(1), 61-106

MS received 28 June 2018 and accepted in revised form 10 October 2018; first published online 14 November 2018 